\title{
Human development and underdevelopment in Brazil ${ }^{1}$
}

\section{Desarrollo y subdesarrollo humano en Brasil}

\author{
Augusta Pelinski-Raiher* \\ Jandir Ferrera-De-Lima**
}

\begin{abstract}
This paper analyzes Brazilian human development profile. The data base was the level of human development comparative performance in Brazilian towns. Also, a logit model with panel data was estimated, aiming at identifying the elements which have some effect on the likelihood of a town to remain or to be inserted in the vicious circle of human underdevelopment over time. The study results pointed out improvements in the human development profile in Brazil, since the number of developed towns increased and there was a reduction in the number of towns which belonged to the human underdevelopment circle.
\end{abstract}

Key-words: human development, urban economy, regional development, underdevelopment, economic development, Brazil.

\section{Resumen}

Este trabajo analiza el perfil de desarrollo humano brasileño. La base de datos fue el desempeño comparativo del nivel de desarrollo humano en las ciudades brasileñas. Además, con el objetivo de identificar los elementos que tienen algún efecto sobre la probabilidad de que una ciudad permanezca o se inserte en el círculo vicioso del subdesarrollo humano a lo largo del tiempo, se estima un modelo logit con datos de panel. Los resultados del estudio indicaron mejoras en el perfil de desarrollo humano en Brasil, ya que aumentó el número de pueblos desarrollados y se redujo el número de ciudades que pertenecían al círculo del subdesarrollo humano.

Palabras clave: desarrollo humano, economía urbana, desarrollo regional, subdesarrollo, desarrollo económico, Brasil.

${ }^{1}$ This paper presents partial results of research funded with resources from the National Scientific and Technological Development Council (CNPq) and the Araucaria Foundation (PR).

*Universidade Estadual de Ponta Grossa, correo-e: apelinski@gmail.com

**Universidad Estatal de Paraná Occidental, correo-e: jandir.lima@unioeste.br 


\section{Introduction}

Knowing the economic development profile and evolution of a region is important, so that public policies aiming at social welfare can be established, and economic and social problems, which are at the forefront of the development process, can be reversed. Since this is an unequal and unbalanced process, some regions might have difficulties to eradicate poverty and advance to a more balanced income stage and social improvement. When certain economy is in the poverty vicious circle, it is characterized by underdevelopment, low productivity of the poor areas, together with their small market, which tend to broaden this underdevelopment even more. This results in strengthening a circular and cumulative process which reinforces poverty instead of eradicating it. That is, the obstacles for the economic development and life condition improvement are reinforced, making that towns and regions immersed in these problems struggle to improve their welfare indicators. Despite these principles were discovered in the 1950s, they are made more and more concrete nowadays, through the development process of theoretical and empirical examination (Nurkse, 1957; Myrdal, 1968; Firjan, 2015; O’hara, 2008).

It seems to be relevant to emphasize that few are the studies which identify factors that can potentially break the poverty vicious circle in towns (Fujita, 2007; O'hara, 2008). One of these is Gallie et al. (2003), with strong evidence that poverty contributed to the exclusion of vicious circles in Europe and that unemployment increases the risk of poverty, which in turn makes the return to the formal market more difficult. In Dao's study (2008), when analyzing some developing countries, strong correlation was found between the portion of inhabitants that lived below the poverty line and education levels, which confirmed the existence of human capital impact on the underdevelopment extension.

In the Brazilian context, Araújo et al. (2013) suggested that poverty is a dynamic and persistent process, since the poverty response ability in the current period, with regards to past values, is high. Therefore, it confirms the vicious circle hypothesis in Brazil. Also, they identified that poverty has a negative effect on the GNP per capita, highlighting the evidence of the existence of a vicious circle. Ramis and Stewart (2000), when analyzing different countries in Latin America, pointed out that throughout the 1960s, 1970s, and 1980s, Brazil tended to show economic growth with low human development. In the 1990s, Brazil entered a pattern of vicious circle, in which the low human development standard limited the economic dynamics, and this limited development.

It seems relevant to emphasize that some of the existing negative cumulative process in Brazil, as well as in Latin America as a whole, partly 
results from the historical dependence built in relation to the developed countries. Nowadays, such dependence exists both at the commercial level and at the financial and technological levels, which means that part of the negative dynamics present in Brazil and other Latin American countries did not only originate from their own characteristics, but also from the dynamics dependence that has been built within a relationship of unequal exchanges in the international trade environment.

Taking that into consideration, this paper analyzes the Brazilian municipal human development profile, from the IFDM (Firjan Municipal Development Index, Brazilian Portuguese acronym) results and evolution. The IFDM data base was used to make a comparison between the Brazilian towns level of development. Moreover, a logit model with panel data was used aiming at identifying the elements that have some effect on the probability of a town remaining or entering the human (under)development vicious circle over time. It is also important to remember that not only does the IFDM provide clues and elements about the town stage in the quality of life ranking, but it also identifies their ability to break the human underdevelopment vicious circle. In this case, the analysis considers all towns which are inserted in the poverty vicious circle, characterized by low health, education, employment, and income indicators as underdeveloped. In such scenery, knowing which of these towns are and the most fragile IFDM components creates opportunities for exogenous actions aiming at breaking the underdevelopment circular and cumulative process and it's retro-feeding. However, for that, it is necessary to identify the ones which are in such situation.

Finally, few are the studies that directly address the vicious circle rupture, especially in Brazil, and that approach it with a multidimensional perspective. These are the main contributions this paper brings to the literature: analysis of Brazilian towns' level of development and factors that increase the likelihood of these towns to enter or remain in the underdevelopment vicious circle.

Regarding the main results observed, Brazil has been seen to improve in terms of human development, increasing the number of towns inserted in the virtuous circle and reducing the number of those previously found in the vicious circle. Also, each town initial conditions are important, however, subsequent changes (regarding income, job market, and human capital, among other aspects) are fundamental to break any negative circular and cumulative process that a town might go through in its human development.

In addition to this introduction, this paper presents three other sections. In the second part, theoretical and methodological elements guiding the research are outlined. Next, the Brazilian towns human development 
profile is presented, followed by the factors that increase the likelihood of a town to remain or enter the underdevelopment vicious circle. The last part presents the conclusions.

\section{Theoretical and Methodological Elements}

The (under)development vicious circle is the result of the interaction of different characteristics, which, in a circular and cumulative process, retro feed themselves. This interdependence is cumulative, so that the size and meaning of this process motivator effects depend on the level of development reached by the region. Therefore, investments in capital and human development tend to minimize the poverty vicious circle negative circular and cumulative effects (Myrdal, 1968; Desbiens and Ferrera de Lima, 2004; Fujita, 2007).

In such context, there is no convergence tendency on a world scale, what exists is, on the one hand, a nucleus of very poor regions, stuck or even presenting deterioration of their human development indicators over time, and, on the other extreme, a development polarization which strengthens more developed economies (Puledo, 2000). As the development/underdevelopment process is founded on cumulative mechanisms, which tend to reinforce and widen positive or negative effects (referring to both the virtuous and the vicious circles), the (under)development profile tends to perpetuate over time.

Regarding less developed countries, there are three vicious circles: 1 . Cultural, in which society lack of education and interest in the social culture hampers human development; 2. Demographic, in which high birth rates and overpopulation increase poverty, preventing birth control; and 3. Economic, in which low income and low work productivity prevent income and product growth. These three circles are interconnected: large families cannot educate their children and cultural issues prevent birth control; lack of education decreases work productivity, reducing earned salaries and low income prevents investments in education; finally, lack of social protection and low income stimulates birth (Coll, 2001).

Another element that might inhibit welfare generation regards corruption. Some studies, such as Akçay (2006), point out the existence of a strong link between corruption and underdevelopment in countries. The author observed that the higher the corruption is in a country, the lower its social indicators are, which worsens the quality of life of its population. And, regarding corruption, Brazil has been seen among the countries with the highest corruption levels in the world, occupying the $79^{\text {th }}$ position in 
morality, politics, and business transparency ranking. Therefore, such characteristic might directly affect its underdevelopment condition.

Gallie et al. (2003), starting with a social exclusion analysis, highlighted that the job market marginality leads to poverty and social isolation. Testing more strictly causal arguments, focusing European families between 1994 and 1996, these authors explored the relation between job market position and poverty status, concluding that there is strong evidence that poverty contributed to the vicious circle exclusion. They also proved that unemployment increases poverty risks, which, in turn, makes the individual return to the job market more difficult.

Other studies point out that the human capital gap is one of the main obstacles to the vicious circle rupture. For example, studies carried out by London and Smith (1988) and Dao (2008) verified that the portion of population which is below the poverty line in developed countries is linearly dependent on the level of education acquired, confirming the hypothesis that the human capital impacts poverty. ${ }^{2}$

In a broader approach, regarding human development, besides salaries and birth rate, access to goods and basic services (public or private) should be considered, mainly those which reflect on the social indicators and people's life maintenance. In the human development process, the cumulative processes should be able to increase the economy product, improve income access, and reduce social gaps through more equalitarian resource distribution, among other factors that lead to the increase of the level of freedom in society (Sen, 2001).

Nurkse (1957) listed lack of productive investment, economic stagnation, insufficient income, and lack of savings, as the determining forces in the socio-economic underdevelopment vicious circle. Likewise, Kindleberger (1958) pointed out that the vicious circle is nothing more than the capital circle, since when the income is too low it is impossible to save

${ }^{2}$ Human capital as a development focus appeared more in the economic growth models from Romer's theory (1994). For that author, it is necessary to introduce in the regions a series of variables which are essential to the economic development, mainly human capital. Without human capital, it is impossible to generate increasing returns to scale. Nowadays, knowledge economy or economy 4.0, based on the advancement of the service sector and digital revolution, has been bringing transformation to the economic dynamics, in which human capital becomes a key element to advance the socio-economic development endogenous capability in the regions. Guaranteeing employment is the best way of improving the families' life conditions, however, due to the digital revolution the job profile has changed and the elements of creativity and knowledge have become essential in the formation of human capital in the XXI century. This means that human development indicators have to evaluate and measure the most significant elements in qualitative terms rather than school attendance. More and more qualitative and intangible elements have become vital in the economic development process. 
or invest to increase income. That is, there is lack of income to generate income. In fact, in order to accumulate savings, parsimony is necessary, which is incompatible with a more equalitarian income distribution. In addition, if saving increase leads to income increase, social investments are very unlikely in this scenery, which deepens the distribution unbalance.

That is, there are circular and cumulative forces which keep the region or town in an underdevelopment status, mainly, when the town presents negative initial characteristics. Therefore, the identification of such regions is vital, so that public policies and civil society mobilization can act to break this circle.

We would like to highlight that in this process of breaking the vicious circle, State intervention becomes a differential. In fact, when Nurkse (1957) described the underdevelopment vicious circle, he emphasized the importance of an external force to interrupt this process, presenting the State, that is, public policies, as a means to create this rupture.

When the individual is taken into consideration, investments in education, and one's human capital, can also optimize the rupture of this cycle. Works such as Becker (1962) and Schultz (1961) pointed out the importance of the human capital to increase the individual's income, which would directly and indirectly maximize their welfare. That is, since the human capital is part of the 'human being', it becomes a non-transferrable factor of production and property. Human capital is a supply of knowledge, breaking the paradigm that the workforce is a homogeneous factor of production. The better qualified, specialized, and educated individual owns certain negotiation power, which tends to value their workforce. In general, the individual's higher qualification/schooling tends to lead them to higher productivity, the creation of innovation, and multiplication of the technological knowledge. It is in this context that the formation of human capital is one of the ways to break the underdevelopment vicious cycle, a rupture that happens not only from the companies but from the individual.

The Human Development Report, Desarrollo Humano (2002), applied a methodology aiming at identifying and classifying Mexican federative units according to their human development profile. Taking the average value in each dimension of the country Human Development Index $(\mathrm{HDI})^{3}$ as a parameter, the federative units were placed in the virtuous

${ }^{3}$ An addition should be included regarding the fundamental principles in the formation of the HDI. The first one refers to the emphasis on people and not in goods. Up to the 1970s, the main focus given to development was on the production and consumption of goods, by employing quantitative indicators as a region development proxy (Boisier, 2001). However, this relation is not necessarily direct. The quality of life depends on the satisfaction of basic human needs, which is not necessarily reached with income. The second principle says that human needs are few and continuous throughout time in different cultures. Many authors, when studying different cultures in different periods of time, found 
circle when the region presented dynamism and magnitude in the HDI three dimensions (income, education, and longevity) with higher values than the national average. Only if the income dimension was above the national average, would the region tend to growth, as it would tend to development if the longevity and/or education average values were also higher. However, if the three HDI dimensions were below the average, the federative unit would fall into the poverty vicious circle.

That methodology was adapted in this study, employing the IFDM Index as a parameter. A minimum limit was established for the development stages different from the one applied by The Human Development Report, Desarrollo Humano (2002): while the latter used each dimension average as the minimum limit, this study employed a fixed value $(0,60$ for all dimensions). The justification for such procedure is: 1 . When the average is considered, there will always be regions below this value, which makes it impossible to measure effectively the evolution between development stages that a town might have over time; 2 . The value 0,60 is considered by the IFDM Index creators as a limit to insert Brazilian towns in a moderate development, as well as the HDI-M that from 0,60 on is considered average development. As this study considered the years 2005, 2010 , and 2013, analyzing the town insertion in each development stage over time, the option for the value 0,60 as a minimum limit (table 1) is justified. All the data was collected from the Industry Federation System of Rio de Janeiro (Firjan, Brazilian Portuguese acronym).

The IFDM - proxy employed to the socio-economic development profile comprises three dimensions: income and employment, health, and education. In the first one, the indicators considered are: formal employment generation, local workforce absorption, formal income generation, formal job average salaries, and income inequality. In the education dimension, the information used is: children education enrolment, elementary school dropout, elementary school age-grade discrepancy, number

out that the fundamental needs do not vary, that is, they are constant and if catered for, tend to generate a significant level of welfare to the population. Other approaches, such as the sustainable economy and the sustainable development, have put forward new principles and values, which are different from those defended by the traditional economy, and which focus more on people and the environment where they live rather than on maximum production and consumption.

It seems important to emphasize that there are other indicators of human development measurement such as the Life Quality Index (LQI), which expresses life quality as perceived by the individual rather than measured by possession of goods, and focuses on the individual's ability to use these goods to obtain satisfaction (Sen,1999). In LQI the range of indicators comprised by the HDI (Human Development Index) is broadened to include childhood and housing. Another indicator used to measure welfare is the Social Development Index (SDI), which measures social justice and basic needs assistance. An extension to this index, corresponds to the Social and Environmental Development Index (SEDI), which includes the discussion on the use of the environment for the development. In this study, these indicators were not used since this information is not available at a municipal level in Brazil. 


\section{Table 1}

\section{Classification of Brazilian Towns Regarding the Human Development Profile Through IFDM}

\begin{tabular}{|c|c|c|c|}
\hline \multicolumn{4}{|c|}{ Town situation } \\
\hline $\begin{array}{l}\text { Tending to economic } \\
\text { growth }\end{array}$ & $\begin{array}{l}\text { Tending to human } \\
\text { development }\end{array}$ & Vicious circle & Virtuous circle \\
\hline $\begin{array}{l}\text { IFDM-employment } \\
\text { and income } \geq 0,60 \text { and } \\
\text { IFDM-health }<0,60 \\
\text { and IFDM-educa- } \\
\text { tion }<0,60\end{array}$ & $\begin{array}{l}\text { IFDM-education } \geq 0,60 \\
\text { a n d / o r I F D M - } \\
\text { health } \geq 0,60 \text { and IFDM- } \\
\text { income and employ- } \\
\text { ment }<0,60\end{array}$ & $\begin{array}{l}\text { IFDM-educa- } \\
\text { tion }<0,60 \text { and } \\
\text { I F D M - } \\
\text { health }<0,60 \\
\text { and IFDM-in- } \\
\text { come and em- } \\
\text { ployment }<0,60\end{array}$ & $\begin{array}{l}\text { IFDM-educa- } \\
\text { tion } \geq 0,60 \text { and } \\
\text { I F D M - } \\
\text { healt } h \geq 0,60 \\
\text { and IFDM-in- } \\
\text { come and em- } \\
\text { ployment } \geq 0,60\end{array}$ \\
\hline
\end{tabular}

Source: elaborated by the researcher, adapted from The Human Development Report, Desarrollo Humano (2002) and Firjan (2015).

of teachers with higher education working in elementary school, and the result of the Basic Education Development Index (IDEB, Brazilian Portuguese acronym). Finally, the health dimension covers the number of pre-natal appointments, death for undefined causes, child death for inevitable causes, and hospital admission related to basic care. ${ }^{4}$

It seems to be relevant to emphasize that identifying the towns in each development stage is not enough. Even if this is a deeply dependent system, the vicious circle can be broken through public policies or even through local community action, when they take control of the development process and start collective actions favoring the improvement of life conditions. Ramis and Stewart (2000), when analyzing a sample of countries in America, Africa, and Asia, identified potential factors to the rupture of the underdevelopment circle such as the reduction of the illiterate population, increase in the social expenses participation in relation to the GNP, the GNP per capita dynamism, in addition to some genre characteristics. Dao (2008), when analyzing countries in development, evaluated the effect of education to stop poverty. Gallie et al. (2003), gathering data from European families, investigated the relation between the job market and the vicious circle exclusion. Approaching the Brazilian situation, Araújo et al. (2013) investigated the causal relation between GNP per capita and poverty, confirming the existence of a poverty vicious circle.

Some works identified factors determining the HDI. Among them, we found Saha (2016), who evaluated a sample of countries, considering the following variables as welfare determiners: education (positive effect),

\footnotetext{
${ }^{4}$ For further information regarding the IFDM calculation methodology, see Firjan (2015).
} 
fertility (negative effect), income concentration (negative effect), GDP (positive effect) and $\mathrm{CO}_{2}$ emissions (negative impact). For Poudyal (2007), the human development of a country depends on three factors: education levels, standard of life, and health status. The income level is also important mainly in countries with low income. Another study that sought to identify HDI determiners was developed by Qasin and Chaudhary (2015), who pointed out social infrastructure, transfers received by families, industrialization, and population density as important elements to generate welfare. These authors drew attention to the need for special public policies for the areas with low human development aiming at improving the individuals' potential.

From these studies and adapting these variables to the existing data of Brazilian towns to evaluate the chances of a town to remain or enter the vicious circle, the following indicators were selected:

1. Percentage of workers with level of education equal or lower than complete elementary school at the initial period (fund $\mathrm{t}_{\mathrm{t}}$ ), seeking to measure how much human capital influences the generation of welfare, with data taken from the (Annual Social Information Report) ASIR. The hypothesis is that the more workers with only fundamental schooling, the lower their productivity and, consequently, the lower their salaries, achieving a smaller amount of goods and services and very low welfare;

2. Percentage of workers with level of education equal or lower than complete elementary school growth rate (tfund), with data taken from the (Annual Social Information Report) ASIR. The hypothesis is that variations at the agents' level of knowledge would lead them to have higher salaries. Therefore, the lower the rate of workers that only have fundamental schooling, the higher the formation of workers' human capital, leading to the region's human development;

3. Percentage of workers with level of education equal or above higher education in the initial period $\left(\sup _{\mathrm{t} 0}\right)$, with data taken from the (Annual Social Information Report) ASIR. It is assumed that workers with higher education present higher productivity, and have the possibility of innovating and multiplying technology. In addition, they tend to have more access to information regarding health, eating habits, culture, among other elements that contribute to the agents' welfare;

4. Percentage of workers with level of education equal or above higher education in the initial period growth rate (tsup), with data taken from the (Annual Social Information Report) ASIR. In 
such case, if a city manages to increase the percentage of workers with higher education, then, it will reach better income dynamics, better level of knowledge, and generation of intangible capital locally, directly affecting human development in this city;

5. Initial per capita GNP (PIB ${ }_{t 0}$ ), with data taken from the Ipeadata, based on the year 2010 (2010=100 - GDP implicit deflator). The hypothesis is that the initial economic condition of a city might, somehow, lead to a cumulative process, resulting in subsequent generation of jobs and income;

6. Per capita GNP growth rate (tPIB), with data taken from the Ipeadata $(2010=100)$. It is assumed that, if a city manages to alter its economic growth pace, it will somehow affect its population welfare, either due to the income generated, the possibility of offering public services, or the general offer of services available, among other elements;

7. Initial formal average wages ${ }^{5}\left(\mathbf{s a l}_{\mathrm{t0}}\right)$, with data taken from the (Annual Social Information Report) deflated by the Consumer Price National Index (INPC, Brazilian Portuguese acronym, $2010=100)$. When this indicator is included, the assumption is that if the workers' initial salary level is high, there is more access to goods services, leisure, and better quality of life;

8. Average formal wage growth rate (tsal), with data taken from the (Annual Social Information Report) (INPC, 2010=100). The hypothesis is that if a city manages to increase its workers' income, the whole population welfare is increased;

9. Initial period existing Establishments (est to $)$ and Establishments growth rate (test) with data taken from the (Annual Social Information Report). Since there is no municipal data regarding the physical capital, and due to the high correlation between the physical capital amount and the number of establishments ${ }^{6}$, the latter was used as the physical capital proxy. Therefore, both indicators, est $_{\mathbf{t} 0}$ and test sought to identify the effect that the municipal physical capital has on welfare generation.

10. Initial period Family Allowance value $\left(\mathbf{b o l}_{\mathrm{t} 0}\right)$, with data from Datasocial, deflated by the $(2010=100)$. The Bolsa Familia Program was implemented in Brazil from 2003 on; it was an income transfer program targeting families in extreme poverty conditions. However, some action is required from the families in exchange to

${ }^{5}$ The wage value was deflated by the Consumer Price National Index (INPC, Brazilian Portuguese acronym), with data from Ipeadata.

${ }^{6}$ By taking the physical capital value in Brazil in the last few years and correlating it to the number of facilities, the value 0,99 was obtained. 
receiving this income: keeping children and teens in school and with their vaccination updated, pregnant women must have health attendance and have their vaccinations updated while breastfeeding. In this sense, it is expected that higher values for the benefits of this program, in the medium term, contribute to the socioeconomic development of cities, mainly due to the realization of conditionalities. The only variable whose growth rate was not applied was the last one, due to the great correlation between its rate and the initial value, therefore, only the initial value granted to the towns was considered. Also, we would like to emphasize that variables that have no reference to rate were worked on with a logarithmic approach.

The fixed effect Logit model ${ }^{7}$ was used with data panel comprising all the Brazilian towns throughout the years 2005, 2010, and 2013. This model estimates the probability of certain events to occur, given a set of explaining variables (Colin Cameron and Trivedi, 2010). In this case, the Logit model identified the likelihood of Brazilian towns to remain or enter the vicious circle (value one for those which were or entered the vicious circle and zero for the remaining cases). With the results obtained in (1) the potential values of the negative cumulative process reversion existing in the towns all over the country were defined. The use of the Logit model seems to be the most suitable, mainly for not requiring multivariate regression normality (Barth, 2004).

$$
\mathrm{h}\left[\frac{p_{i t}}{1-p_{i}}\right]=x_{i} \beta^{\prime}+c_{i}+\varepsilon_{i}
$$

Where: $\mathbf{p}$ is the probability of remaining or entering the vicious circle and 1-p is the probability of not being or not entering the vicious circle; $\mathbf{x}_{\mathrm{it}}$ are the exogenous variables which vary in time $(\mathbf{t}) ; \mathbf{c}$ is the individual effect which does not vary in time; and $\varepsilon$ is the random error.

The explaining variables for (1) corresponded to: fund $\mathbf{t}_{\mathbf{t}}, \mathbf{t f u n d}_{\mathbf{1}} \boldsymbol{s u p}_{\mathbf{t} \mathbf{0}}$,

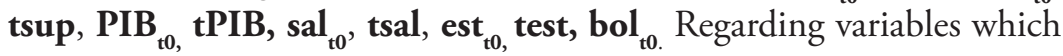

${ }^{7}$ It seems relevant to highlight that, in this kind of model, one of the hypothesis is that the difference between the distributed errors is in accordance with the extreme values and present independent normal distribution. This independence means that the unnoticed part of an alternative usefulness is not related to the part of the alternative that is not observed. If the hypothesis is that the part that is not observed is correlated between the alternatives, then, one of the options is to use the logit as an approximation model. This applies, minimizing the violation of presumptions, when the estimate seeks to achieve average predictions rather than when it aims at substitution patterns (Train, 2014). 
are rates, as there is difference of years between the periods, the growth annual values were obtained. For the first year (2005), the initial explaining variables corresponded to 2004 . The growth rate, also used for the first year (2005), corresponded to 2004-2005.

It seems relevant to highlight that the data base available was from 2004-2013; therefore, that was the analyzed period. The sample used in estimate (1) corresponded to the 5570 Brazilian towns, analyzed for three years, resulting in a panel with 16,710 observations.

One can estimate (1) considering $\mathbf{c}_{\mathbf{i}}$ as a parameter obtained together with $\beta$ (fixed effect mode $-\mathrm{FE}$ ) or as a not observed random variable (random effect model - RE). Through the Hausman test (value equal 161,3), FE was indicated as the most suitable model; however, we also opted to present the RE model results to demonstrate the result robustness. Moreover, it seems to be relevant to emphasize that the panel-robust error correction method was used to correct standard errors of any time dependency of certain individual.

\section{Brazilian town development profile}

The results presented in figure $1(a)$ demonstrate the Brazilian town development profile in 2005 , focusing mostly on the vicious circle (39\%). This situation changed in the following years [figures I $(b)$ and $(c)$ ] and in 2013 only $8 \%$ of the towns were in this process. In eight years, 1730 Brazilian towns left the underdevelopment vicious circle and reached significant gain in terms of human development.

At the same time, the percentage of those which were in the virtuous circle increased, going from 12\% in 2005 to $19 \%$ and $20 \%$ in the following years. The same happened with those which tended to development, corresponding to over $70 \%$ of the towns in 2013. Conversely, in the category tending to growth, the percentage of involved towns reduced from 6\% in 2005 to only $1 \%$ in 2013 (table 2).

Brazil improved in terms of human development and advanced to enlarge the virtuous circle, with a significant decrease in towns that belonged to the underdevelopment vicious circle. Unlike 2005, when the towns were most in the vicious circle or tending to development, in 2013, most of them were in stages tending to development or in the virtuous circle.

In the analysis of towns categorized in transition stages, there was a sharp increase of those tending to development, and this stage predominated within the years. Regarding the towns classified as tending to growth, 
Figure 1

Human Development in Brazilian Towns - 2005 (a), 2010 (b), and $2013(c)$

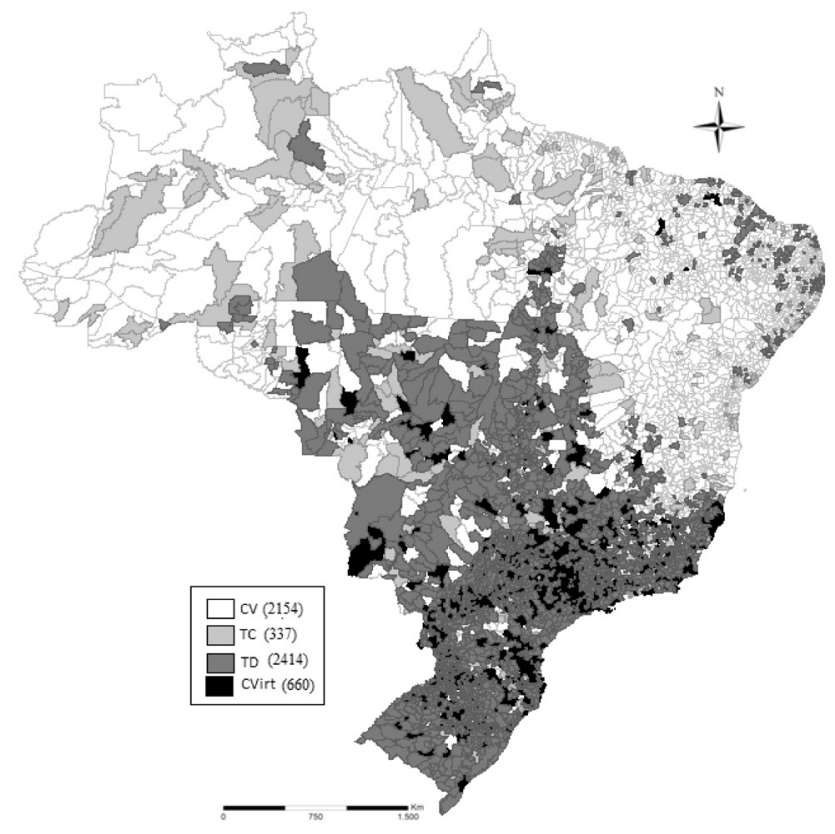

a)

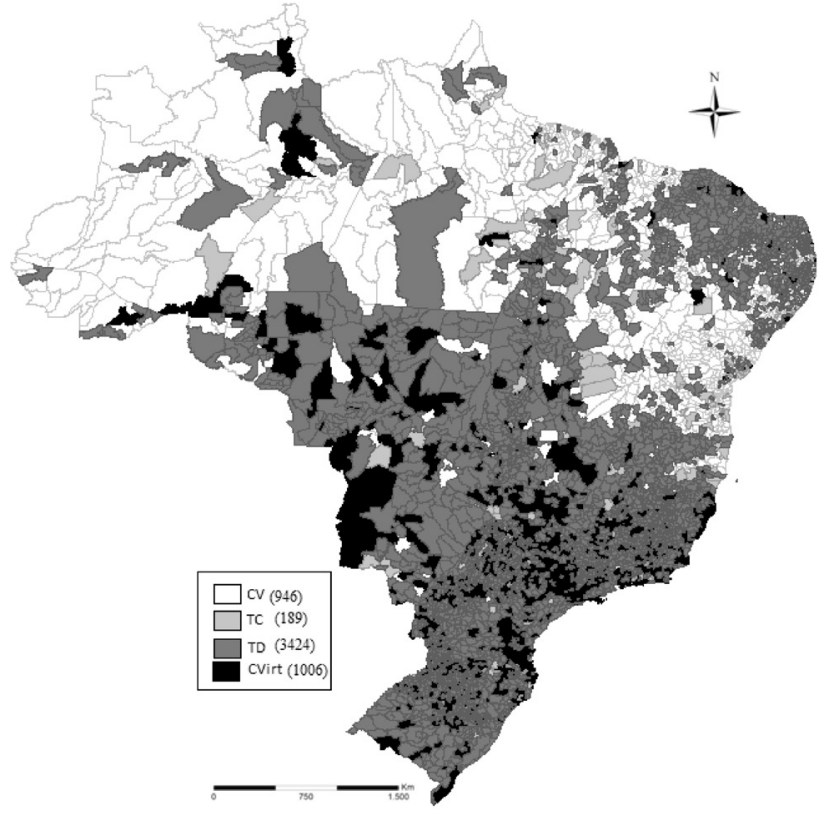

b) 


\section{Figure 1}

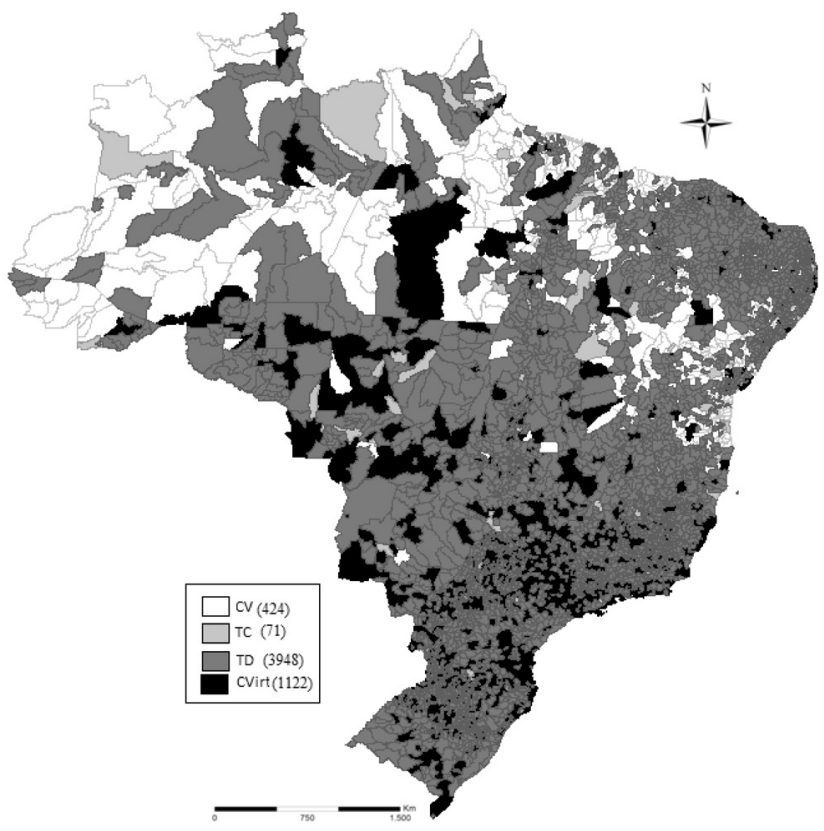

c)

Source: original data in the Firjan System, worked by the researcher.

Note: CV: vicious circle; TC: tending to economic growth; TD: tending to human development; CVirt: Virtuous circle.

Table 2

Number of Brazilian Towns in Each Stage of Human Development - 2005, 2010 and 2013

\begin{tabular}{lccc}
\hline \multicolumn{1}{c}{ Development stage } & 2005 & 2010 & 2013 \\
\hline Vicious circle (CV) & 2154 & 946 & 424 \\
Virtuous circle (CVirt.) & 660 & 1006 & 1122 \\
$\begin{array}{l}\text { Tending to human develop- } \\
\text { ment (TD) }\end{array}$ & 2414 & 3124 & 3948 \\
$\begin{array}{l}\text { Tending to economic growth } \\
\text { (TC) }\end{array}$ & 337 & 189 & 71 \\
\hline
\end{tabular}

Source: original data from the Firjan System, worked by the researcher. 
there was a decrease (table 2 and figure 1). By analyzing this stage more specifically, $44 \%$ of the towns found in this profile in 2005 were seen to evolve to the classification tending to development in 2013 and 39\% moved to the virtuous circle (table 3 ). Referring to the ones that tended to development in 2005, over half of them remained in this classification and $18 \%$ progressed to the virtuous circle.

Table 3

Dynamics of Brazilian Towns in Each Stage of Human Development - 2005 to 2013

\begin{tabular}{lccccc}
\hline \multirow{2}{*}{ Stage } & Total of towns in 2005 & \multicolumn{4}{c}{ Situation of towns in 2013 } \\
\cline { 3 - 6 } & & $C V(\%)$ & $\begin{array}{c}\text { CVirt. } \\
(\%)\end{array}$ & TC (\%) & TD (\%) \\
\hline CV & 2154 & 17.6 & 2.2 & 1.4 & 78.7 \\
CVirt. & 660 & 0.2 & 78.2 & 0.8 & 20.9 \\
TC & 337 & 11.6 & 38.6 & 5.9 & 43.9 \\
TD & 2414 & 0.2 & 17.7 & 0.6 & 81.5 \\
\hline
\end{tabular}

Source: original data from the Firjan system, worked by the researcher.

Note: CV: vicious circle; TC: tending to economic growth; TD: tending to human development; CVirt: Virtuous circle.

One important fact verified in these results is that from those towns which were initially in the stage tending to development only a few dropped to the vicious circle (only $0,2 \%$ ), while from those tending to growth in $2005,11 \%$ dropped to the vicious circle in 2013. That is, the acceleration in the economic growth was a relevant element to the advancement in the most qualitative stages of the socio-economic profile of the Brazilian towns, but this does not guarantee that the towns are able to make the transition. On the other hand, the towns that reached a more advanced stage in capital and human development qualitative terms improved their position in the economic and social development profile. Therefore, there is a more significant predisposition of those which tended to growth to go back to the vicious circle in the medium and long term if they do not keep the dynamism of their economies and advance in terms of human and social capital. In such case, the advance of municipal economies, only in income and employment, is not enough to keep the economic development process, mainly if those economies are not able to advance in qualitative aspects which characterize human development (education and health). This reinforces Sant'Ana (2008) thesis that improving only economic aspects cannot guarantee that the town will not enter the vicious circle, it is only 
a necessary dimension, which is not enough to generate improvement to the population welfare.

Regarding those Brazilian towns which were classified within the virtuous circle in 2005, most of them (78\%) remained in this process. Therefore, we understand that once the human development process is started, the chances of going back are lower due to the cumulative process, since the necessary elements to reach higher welfare levels of the population and reinforcing equality are constantly reinforced.

The circular and cumulative process can also occur with towns that are in the vicious circle, but in such case, the cumulative process reinforces negative aspects, intensifying and widening the local population human underdevelopment. A town in the vicious circle presents serious problems regarding its capability to generate employment and income and, consequently, it reaches tax gains to expand coverage and investments in health and education. However, if the effort to improve human capital conditions is kept, either in the endogenous or exogenous manner, it is possible to change the socio-economic state of development. Regarding Brazilian towns, most of those which were in the vicious circle in 2005 managed to reach greater mobility in the following years. With that, they evolved to other stages of development, and only $17,6 \%$ of the towns remained in the vicious circle. The towns which remained in the vicious circle were found in a more difficult situation to reverse the human underdevelopment process in an endogenous manner.

Using the classification obtained in 2005 and analyzing the IFDM evolution between 2005 and 2013 (table 4), it was seen that the great differential in terms of the towns found in the vicious circle were health and education dimensions (56\% and 53\% average growth, respectively)

\section{Table 4}

\section{Firjan Municipal Development Index Average for the Three Dimensions When Considering the Stage in Which the Brazilian Towns Were in 2005}

\begin{tabular}{lcccccccccc}
\hline \multirow{2}{*}{ Stage 2005 } & \multicolumn{3}{c}{ Income and Employment } & \multicolumn{3}{c}{ Health } & \multicolumn{4}{c}{ Education } \\
\cline { 2 - 10 } & 2005 & 2010 & 2013 & 2005 & 2010 & 2013 & 2005 & 2010 & 2013 \\
\hline Vicious circle & 0.38 & 0.40 & 0.40 & 0.39 & 0.55 & 0.61 & 0.43 & 0.58 & 0.66 \\
TC & 0.69 & 0.52 & 0.50 & 0.48 & 0.58 & 0.64 & 0.44 & 0.56 & 0.63 \\
TD & 0.45 & 0.49 & 0.50 & 0.71 & 0.76 & 0.79 & 0.66 & 0.75 & 0.80 \\
Virtuous circle & 0.69 & 0.69 & 0.67 & 0.78 & 0.81 & 0.84 & 0.75 & 0.81 & 0.85 \\
\hline
\end{tabular}

Source: original data from the Firjan System, worked by the researcher.

Note: TC: tending to economic growth; TD: tending to human development. 
which also had greater advances in other classifications. These results reinforce Haddad's (2009), London and Smith's (1988) and Schultz's (1987) thesis that when aspects related to human capital, mainly health and education are improved, life conditions and the regional socio-economic profile are improved. Nakabashi and Figueiredo (2008), for example, exposed three courses of action of the human capital in the economy: 1 . Increasing the work productivity; 2 . Producing technologies: 3. Disseminating technologies. Therefore, the improvement seen in IFDM-education and IFDM-health in the country within the last few years, mainly in those towns inserted in the underdevelopment vicious circle, there was an important element to increase social welfare, together with the homogenization of economic development in the long term.

In the Brazilian case, the research results demonstrated that the problem appeared when the income dimension was analyzed, whose average value decreased in some stages, and had very little growth in others. Although that is not a sufficient dimension, it is necessary. Without income, the individuals' autonomy and freedom as consumers is broken, and they cannot acquire the necessary goods for survival, stopping the growing process and subsequent economic development. The main explanation for the fall in economic aspects is in the crisis that started in 2008, which still has consequences in the country nowadays. That is, the tendency is to go back to the vicious circle if unemployment and the economic crisis scenery remains.

According to Myrdal (1968), regarding the circular and cumulative causation, the circles are interrelated. In this sense, if the education and health dimensions (human capital) had great advancement lately, what is expected ex-post is a positive response from the income dimension. Nevertheless, considering the results verified, this retro-feeding effect was not enough to inhibit the effects of the crisis in the economic activity of great part of the towns in the country. In such case, the maintenance of income indicators also depends on the variable investment, whose attraction is linked to human capital, but also the market conditions and expectancies related to the future of the economic activity. This partly explains why $81,5 \%$ of the towns that tended to development remained in this classification in 2013, going against the Ramis and Stewart (2000) hypothesis that no unbalance persists over time. That is, unbalance can deepen if corrective actions or measures do not occur.

Analyzing each Brazilian macro region (table 5), the privileged position of south and southeast regions regarding welfare generation becomes evident when compared to the other regions, obtaining higher percentage of towns in the virtuous circle, in 2005, 2010, and 2013. 
The south and southeast regions reached 2013 with 35\% and 28\% towns inserted in the virtuous circle, respectively. While north and northeast regions presented only 5,6\% and 4,5\%, sequentially. This demonstrates that the development discrepancy is still huge when the regions are compared, and the main development gaps are still found in these two regions, although this process has slowed down with significant part of the towns which were in the vicious circle having moved to the intermediate stage tending to development. In this sense, aspects related to education and/or health have been improved in these regions, but it is still necessary to boost more intensely the economic dynamism of these spaces, either with endogenous or exogenous measures.

Along the period, center-west region outstood with sharp increase in the towns belonging to the virtuous circle, reaching a percentage close to that of the southeast region. Regarding the center-west region, it is relevant to mention some particularities: the first element is the character of mo-

Table 5

Regional Distribution of Towns According to Their Human Development Profile - Brazilian Regions - 2005, 2010, and 2013

\begin{tabular}{lcccccc}
\hline \multicolumn{1}{c}{ Region } & Year & Total of towns & $\begin{array}{c}\text { Vicious circle } \\
(\%)\end{array}$ & $\begin{array}{c}\text { TC } \\
(\%)\end{array}$ & $\begin{array}{c}\text { TD } \\
(\%)\end{array}$ & $\begin{array}{c}\text { Virtuous circle } \\
(\%)\end{array}$ \\
\hline North & 2005 & 449 & 61.0 & 15.6 & 22.3 & 1.1 \\
& 2010 & 449 & 48.3 & 4.9 & 41.9 & 4.9 \\
& 2013 & 449 & 28.3 & 2.7 & 63.5 & 5.6 \\
North-east & 2005 & 1794 & 81.3 & 7.4 & 11.0 & 0.3 \\
& 2010 & 1794 & 38.2 & 6.0 & 53.1 & 2.8 \\
& 2013 & 1794 & 16.3 & 1.9 & 77.3 & 4.5 \\
Center-west & 2005 & 466 & 19.7 & 8.6 & 61.6 & 10.1 \\
& 2010 & 466 & 4.5 & 2.6 & 71.7 & 21.2 \\
& 2013 & 466 & 0.9 & 2.1 & 69.7 & 27.3 \\
South-east & 2005 & 1668 & 16.7 & 3.8 & 58.9 & 20.5 \\
& 2010 & 1668 & 1.3 & 1.8 & 67.9 & 29.0 \\
& 2013 & 1668 & 0.1 & 0.6 & 71.2 & 28.2 \\
\hline \multirow{5}{*}{ South } & 2005 & 1188 & 4.3 & 2.5 & 71.3 & 21.9 \\
& 2010 & 1188 & 0.1 & 1.5 & 68.9 & 29.5 \\
& 2013 & 1188 & 0.0 & 0.4 & 64.3 & 35.3 \\
\hline
\end{tabular}

Source: original data from the Firjan System, worked by the researcher.

Note: TC: tending to economic growth; TD: tending to human development. 
bility in its land occupation, that is, the agricultural border in the Brazilian center-west has not been exhausted yet, incorporating new productive areas and allocating agrarian capital year after year. The second element is the urban expansion together with the population flow towards the agricultural border and, consequently, stimulating the urbanization process. The third particularity is the creation of the State of Tocantins, whose installation started in the 1990s attracting federal investments and the transfer of federal resources, both to structure the State bureaucracy and to improve the competitiveness of productive activities in the Brazilian cerrado.

Martine and Diniz (1991) and Piacenti et al. (2008) emphasize the center-west advance by drawing attention to the context in which the polarization reversion and the advance of Brazilian peripheral regions are produced, which comprises: 1 . The need to expand agro-industrial processing companies and the advancement of the third sector, stimulated by urbanization, both to conquer new markets and also, in the case of the agro-industry, to guarantee the offer of raw material and exportable commodities; 2. Governmental policies, mainly those linked to the infrastructure, tax incentives, colonization and support to agriculture, and cattle raising, which stimulate investments and the opening of new agricultural areas. Regarding infrastructure, new railways, roads, and harbors are elements that have great effect on capital efficiency in the region; 3. Agglomeration diseconomies, which stimulate population displacement searching for employment and better life conditions, and also stimulate the companies to seek new regions with lower transaction costs.

Finally, these elements help to explain the undeniable advance that all Brazilian peripheral regions had, and the results are not better due to the economic dynamism which inhibited the passage of many towns from the stage tending to development to the virtuous circle. Therefore, actions mainly in this area must be made effective, leading to expansion of the economic activity throughout the country.

Considering the virtuous circle, the research results pointed out that this situation retracted in all Brazilian regions. The number of towns inserted in the stage poverty vicious circle or underdevelopment became below $1 \%$ in the south, south-east and center-west regions. However, from the towns which are still in this stage (380 altogether), $71 \%$ are in the northeast region and $28 \%$ in the north region, which demonstrates the underdevelopment spatial persistence in some Brazilian areas (figure II).

In fact, when the town is inserted in a human development positive circular and cumulative process, better development conditions to the population are a natural consequence of the internal results that the development process itself produces. Conversely, when the region has 
Figure 2

Towns that remained in the vicious circle (CV) of Human

Development, 2005/2013, Brazil

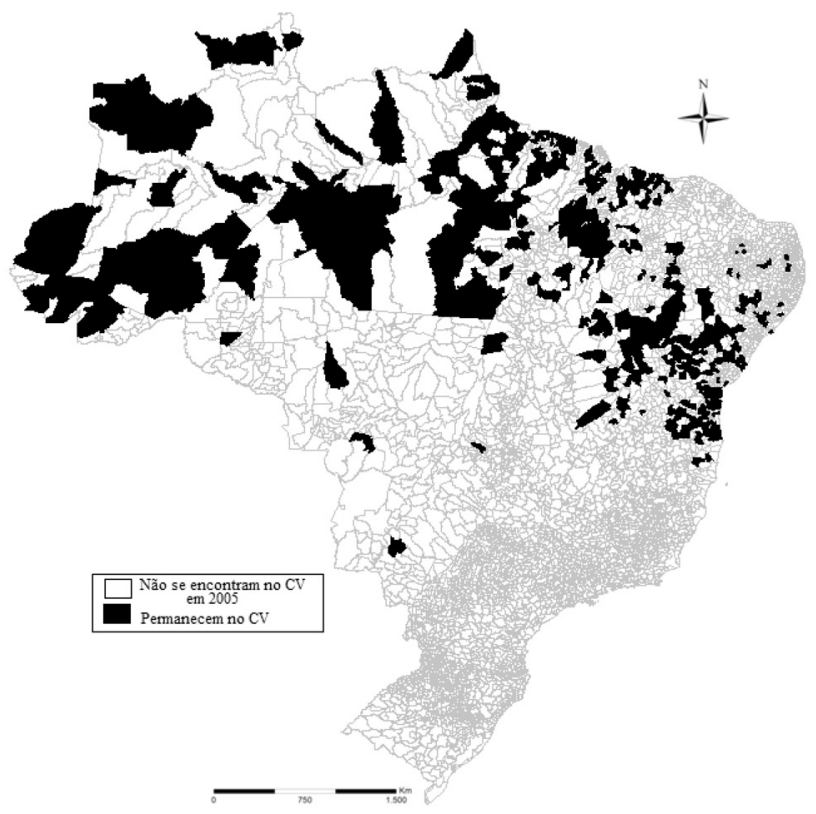

Source: original data from the Firjan System, worked by the researcher.

rooted negative indicators, the human underdevelopment spiral only tends to intensify. Therefore, it is crucial to identify the potential elements which might break this process and progressively improve the municipal human development profile and the consequences to the region.

In table 6, some of the factors that might have induced the inertia in terms of the IFDM profile revealed in figures 1 and 2 are exposed. Therefore, aiming at identifying the elements that have great effect on the probability of a town to remain or enter the human (under)development vicious circle over time, a fixed effect Logit model was estimated, using a data panel comprising all Brazilian towns in the years 2005, 2010, and 2013. The research results revealed that the initial conditions regarding workers' schooling, formal work average wage, GNP per capita, and the number of facilities (proxy for physical capital), had some effect on the likelihood of remaining or entering the vicious circle. It was also emphasized that changes in these elements over time can also impact this likelihood. 
Table 6

Logit model results regarding the chances of a town to remain or enter the human underdevelopment vicious circle - Brazilian Towns

\begin{tabular}{|c|c|c|}
\hline \multirow[t]{2}{*}{ Explaining variables } & \multicolumn{2}{|c|}{ Method } \\
\hline & Fixed effect & Random effect \\
\hline fundt0 & $\begin{array}{c}0.58 \\
(0.02)^{*}\end{array}$ & $\begin{array}{c}0.18 \\
(0.03)^{*}\end{array}$ \\
\hline Tfund & $\begin{array}{c}0.002 \\
(0.04)^{*}\end{array}$ & $\begin{array}{c}0.0003 \\
(0.06)^{* *}\end{array}$ \\
\hline supt0 & $\begin{array}{c}-0.62 \\
(0.00)^{*}\end{array}$ & $\begin{array}{c}-0.92 \\
(0.00)^{*}\end{array}$ \\
\hline Tsup & $\begin{array}{l}-0.002 \\
(0.02)^{*}\end{array}$ & $\begin{array}{c}-0.002 \\
(0.00)^{*}\end{array}$ \\
\hline PIBt0 & $\begin{array}{c}-7.52 \\
(0.00)^{*}\end{array}$ & $\begin{array}{c}-3.91 \\
(0.00)^{*}\end{array}$ \\
\hline tPIB & $\begin{array}{c}-0.09 \\
(0.00)^{*}\end{array}$ & $\begin{array}{c}-0.05 \\
(0.00)^{*}\end{array}$ \\
\hline salt0 & $\begin{array}{c}-0.45 \\
(0.00)^{*}\end{array}$ & $\begin{array}{c}-0.58 \\
(0.00)^{*}\end{array}$ \\
\hline Tsal & $\begin{array}{c}-0.0004 \\
(0.03)^{*}\end{array}$ & $\begin{array}{c}-0.0002 \\
(0.12)\end{array}$ \\
\hline estt0 & $\begin{array}{c}-1.15 \\
(0.08)^{* *}\end{array}$ & $\begin{array}{c}-0.19 \\
(0.00)^{*}\end{array}$ \\
\hline Test & $\begin{array}{c}-0.01 \\
\left(0.050^{*}\right.\end{array}$ & $\begin{array}{c}-0.002 \\
(0.09)^{* *}\end{array}$ \\
\hline bolt0 & $\begin{array}{l}-0.06 \\
(0.79)\end{array}$ & $\begin{array}{l}-0.006 \\
(0.90)\end{array}$ \\
\hline
\end{tabular}

Source: research results.

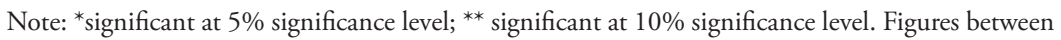
brackets refer to the $\mathrm{t}$ test $\mathrm{p}$-value.

More specifically it was seen that the increase in variables percentage of workers with level of education equal or above higher education in the initial period, initial GNP per capita, initial formal average wage, and existing facilities in the initial period, decreased the likelihood of entering the vicious circle. At the same time, when the percentage of workers with level of education equal or lower than complete elementary school in the initial period decreased, ceteris paribus, this likelihood also decreased. That is, the initial characteristics are determining in the conduction of subsequent human development in Brazilian towns. 
However, the most important is that if positive changes occurred regarding the population social welfare in the following years, the human underdevelopment process can be reversed. When analyzing the percentage of workers with level of education equal or above higher education in the initial period growth rate impact, GNP rate per capita, formal average wage growth rate, and facilities growth rate, it was possible to see that all influenced negatively the town likelihood of remaining or entering the human underdevelopment vicious circle. Also, changes in the percentage of workers with level of education equal or lower than complete elementary school had positive influence, that is, development requires more improvement in the region of human capital.

Finally, initial conditions are important, but subsequent changes are fundamental to the rupture of any negative circular and cumulative process that a town might have in its human development. In this sense, if public policies do not prioritize towns in which the human underdevelopment is rooted, promoting alteration in its internal characteristics, the changes of ruining the population welfare, and consequently their human development are increased. That is, public policies should always prioritize more fragile towns in terms of human development. It is important to highlight that it is not necessarily relevant to increase the amount of public expenditure to promote such intervention. A study carried out by Barros and Foguel (2000) evidenced that focusing public expenditure, regarding the need to ameliorate public policies, is the fundamental action. It is even more important than the increase in resources, even the social ones.

Therefore, the only social expenditure included in the estimates (family allowance value) appeared with the expected signal (negative), however, this was not significant. Maybe the results of this policy will be seen in the long term, given the quid pro quos demanded, but in a period of eight years, there was no significant effect.

On the other hand, improvement in the job market characteristics presented higher effect on the rupture of the vicious circle, either for elevating workers' education levels, or for increasing the actual earned wage, corroborating results presented by other authors such as Gallie et al. (2003) and Dao (2008). Just like Nurkse's (1957) argument regarding the importance of increasing capital accumulation to break the poverty vicious circle was confirmed.

This rupture, occurring in one or another way - either for increasing education levels, income, or others - is crucial in order to provide more egalitarian human development over time in Brazil. 


\section{Conclusion}

This paper analyzed the Brazilian municipal human development profile, from the Firjan Index of Municipal Development (IFDM) results and evolution.

The methodological procedure led to a comparison between the human development stage in Brazilian towns and its profile in Brazilian regions. Also, a logit model with panel data was estimated, aiming at identifying elements which have effect on the likelihood of a town to remain or enter the (under)development vicious circle along time.

The research results revealed improvement in the human development indicators, since together with the broadening of the virtuous circle there was also reduction in the towns belonging to the human development vicious circle. Likewise, there was higher predisposition of the towns in the stage tending to growth to fall into the vicious circle over time. Therefore, public policies that contribute with the existing positive economic characteristics are necessary, in order to promote other positive social elements which can improve the whole population welfare.

Another important element revealed by the research results was that having positive social aspects does not guarantee socio-economic development, since the variable income is also relevant in this process. That is, along the human development process, Brazilian towns should be able to create better conditions of employment and income together with improvements in social indicators. Even if not sufficient, economic dynamism is also necessary so that better living conditions are achieved.

Initial conditions regarding schooling and formal market salaries, GNP per capita, and physical capital interfere in the likelihood of a town to remain or enter the vicious circle. It seems relevant to mention that the dimension income, in the Firjan index, is connected to the dimension employment. The creation of new jobs assumes that they are dignifying, which in the Brazilian case are reflected by the worker's formalization. In the same context, over time, with human capital qualitative improvement (education and health) and economy expansion, the wage profile and number of formal employees should also grow. If economy grows strengthening underemployment and informality, then the qualitative aspect cannot create conditions to break the vicious circle.

Therefore, when an advanced stage of human development is achieved, advancement in the development conditions is a natural consequence of the socio-economic development process. But, when the region presents a poverty history and indicators with little significance in terms of human and social capital, the socio-economic development indicators tend to aggravate. This fact requires the identification and monitoring of potential 
elements that might break this process and progressively improve living conditions. Therefore, once the human development process is started, chances of regression are lower due to the circular and cumulative process. That is, all the time the necessary elements to reach higher welfare levels for the whole population are reinforced. Taking that into consideration, one can conclude that the initial conditions of the development process are important, but the subsequent changes are fundamental to break any negative circular and cumulative process that a town might have in its human development over time.

Taken these results into account, the conclusion is that the creation of public policies acting more effectively to break the negative cumulative processes of human underdevelopment is necessary. Public policies should provide people's education and qualification, empowering them so that they can achieve welfare. In addition, other measures, which are not necessarily related to income generation might be implemented, such as: improvement of health and public safety, cultural activities offer, etc. It was seen that in poorer regions, such as the Brazilian northeast, public policies were intensified in the 2000s (mainly regarding education and health). The result was an increase in the number of towns that left the vicious circle of underdevelopment. The results of this research showed that it is possible to break the cumulative process of underdevelopment, mainly when structural changes in the economy occurred, starting a process of welfare autonomy.

Nowadays, with the advancement of the so-called economy or industry 4.0, decision making becomes faster and more and more technological advancement favored by the digital revolution has been changing the production and services profile. In such environment, the conventional productive structure that was created from the industrial revolution starts to demand a different pattern of human resources. Therefore, human capital becomes differentiated, since digital revolution changes the profile of jobs, qualification, and the way companies are managed. More and more knowledge economy requires a higher level of human development, in which creativity and knowledge are the great differentials in terms of advancement in the development process. In the economy 4.0, the concepts of underdevelopment and development are increasingly based on the competences of human capital. Instead of classifying countries or regions as developed or underdeveloped, knowledge economy will reveal countries with high or low potential of human capital. The development structure is dislocated from the physical capital to the human capital. And the results of this study point that out, even if Brazil has not advanced significantly in the economy or industry 4.0. 
However, since there is great heterogeneity in the Brazilian space as a whole, it is relevant that other studies be developed focusing more specifically on the determiners of the human underdevelopment vicious circle, analyzing each region of the country. Based on the results of a more particular evaluation, specific public policies might be more efficient, favoring Brazilian human development. ${ }^{8}$

\section{References}

Akçay, Selçuk (2006), "Corruption and human development", Hein Online, 26 (1), Hein Online, Washington, United States of America, pp. 1-29.

Araújo, A. J. Campelo, Guaracyane Campelo and Emerson Marinho (2013), O impacto da infraestrutura sobre a pobreza para o Brasil, Anpec, Anais, Natal, Brazil, <http://www.anpec.org.br/encontro/2013/files_I/i12-845a1ff97efe102932cbda215972c2d.pdf>, 20 January 2016.

Barros, Ricardo Paes and Miguel Foguel (2000), "Focalização dos gastos públicos sociais e erradicação da pobreza no Brasil", in: Henrique Ricardo (ed.), Desigualdade e pobreza no Brasil,Instituto de Pesquisa Econômica Aplicada, Rio de Janeiro, Brazil, pp. 719-739.

Barth, Nelson Lener (2004), Inadimplência: construção de modelos de previsão, Nobel, São Paulo Brazil.

Becker, Gary (1962), "Investment in human capital: a theoretical analysis", Journal of Political Economy, 70 (5), The Univesity Chicago, Chicago, United States of America, pp. 9-49.

Boisier, Sergio (2001), De que estamos hablando?, in: Transformaciones globales, instituciones y politicas de desarrollo local, Homo Sapiens ediciones, Rosario, Argentina.

Colin-Cameron, A. and Pravin K. Trivedi (2010), Microeconometrics using Stata, Stata Press, Texas, United States of America.

\footnotetext{
${ }^{8}$ In other studies, the logit model could help to guarantee the identification of successful or unsuccessful cases of poverty rupture, being or not in a common vicious circle and inherent in culture, politics, economy, and society; or even, reach or not a common human capital in the virtuous circle, and proceed or not with an economy 4.0 to achieve knowledge production.
} 
Coll-Martínez, Juan Carlos (2001), El crecimiento económico en la economía de mercado, virtudes e inconvenientes, Eumed, Málaga, Spain, <http:// www.eumed.net/cursecon/18/index.htm>, 20 January 2015.

Dao, Minh Quang (2008), "Capital, poverty and distribution of human income in developing countries", Journal of Economic Studies, 35 (4), Milwaukee, United States of America, pp. 294-303.

Desbiens, Yvan and Jandir Ferrera de Lima (2004), "Cadrage du développment regional”, Revista Interfaces Brasil/Canadá, 4 (1), Associação Brasileira de Estudos Canadenses, Rio Grande do Sul, Brazil, pp. 179-192.

Firjan (Federation of Industries of the state of Rio de Janeiro) (2015), Índice Firjan de desenvolvimento municipal, Firjan, Rio de Janeiro, Brazil, <http:/publicacoes.firjan.org.br/ifdm/2015/\#2>, 20 February 2016.

Fujita, Nanako (2007), "Myrdal's Theory of Cumulative Causation", Evolutionary and Institutional Economics Review, 3 (2), Japan Association for Evolutionary Economics, Heidelberg, Germany, pp. 275-284.

Gallie, Duncan, Serge Paugam and Sheila Jacobs (2003), "Unemployment, poverty and social isolation: Is there a vicious circle of social exclusion?", European Societies, 5 (1), European Sociological Association, Paris, France, pp. 1-32.

Haddad, Paulo (2009), "Capitais intangíveis e desenvolvimento regional", Revista de Economía, 35 (3), Fundação Getúlio Vargas, Rio de Janeiro, Brazil, pp. 119-146.

Informe Sobre Desarrollo Humano (2002), La dinámica del desarrollo humano regional, United Nations Development Program, New York, United States of America, < http://www.centrodesarrollohumano.org >,15 December 2014.

INPC (National Consumer Price Index) (2010), Preços, Instituto de Pesquisa Econômica Aplicada, Rio de Janeiro, Brazil.

Kindleberger, Charles Poor (1958), Economic development, Mc Graw Hill, New York, United of States of America. 
London, Bruce and David Smith (1988), "Urban bias, dependence, and economic stagnation in noncore Nations", American Sociological Review, 53 (3), American Sociological Association, Washington, Unites States of America, pp. 454-463.

Martine, George and Campolina Diniz Clelio (1991), "Concentração econômica e demográfica no Brasil: recente inversão do padrão histórico, Revista de Economía Política, 11 (3), Editora 34, São Paulo, Brazil, pp. 121-135.

Myrdal, Gunnar (1968), Teoría económica y regiones subdesarrolladas, Fondo de Cultura Económica, Ciudad de México, México.

Nakabashi, Luciano and Lízia Figueiredo (2008), "Mensurando os impactos diretos e indiretos d o capital humano sobre o crescimento", Economia Aplicada, 12 (1), Universidade de São Paulo, São Paulo, Brazil, pp. 151-171.

Nurkse, Ragnar (1957), Problemas da formaçâo de capital em paises subdesenvolvidos, Editora Civilização Brasileira, Rio de Janeiro, Brazil.

O'hara, Phillip Anthony (2008), "Principle of circular and cumulative causation: fusing Myrdalian and Kaldorian growth and development dynamics", Journal of Economic Issues, 42 (2), Taylor and Francis, New York, United States of America, pp. 375-387.

Piacenti, Carlos Alberto; Lucir Alves and Jandir Ferrera de Lima (2008), "O perfil locacional do emprego setorial no Brasil", Revista Econômica do Nordeste, 39 (3), Escritório Técnico de Estudo Econômicos do Nordeste, Fortaleza, Brazil, pp. 482-502.

Poudyal, Niraj (2007), "Socio Economic Development Panorama”, Nepal Journals Online, 1 (1), NepJOL, Kathmandu, Nepal, pp. 1-11.

Puledo, Antonio (2000), Economía em accion, Pyramid, Madrid, Spain.

Qasin, Muhammad and Amatul Razzaq Chaudhary (2015), "Determinants of human development disparities: a cross district analysis of Punjab, Pakistan", Pakistan Development Review, 54 (4), National College of Business Administration and Economics, Lahore, Pakistan, pp. 427-450. 
Ramis, Gustave and France Stewart (2000), "Strategies for success in human development", Journal of Human Development, 1 (1), Taylor and Francis, New York, United States of America, pp. 49-69.

Romer, Paul (1994), "Origins of Endogenous Development", Journal of Economic Perspectives, 8 (1), AEA Publications, Pittsburgh United States of America, pp. 3-22.

Sant'Ana, Matthias (2008), "The evolution of the concept of development: from economic growth to human development", Working PaperPAI VI/06-FDI/HD, 1 (6), Inter-University Attraction Pole VI/06, Leuven, Belgium.

Saha, Smit (2016), Determinants of human development index: A crosscountry empirical analysis, National Institute of Bank Management, Pune, India.

Schultz, Theodore (1961), "Investment in human capital", The American Economic Review, LI (1), American Economic Association, Nashville, United States of America, pp. 1-17.

Schultz, Theodore (1987), Investindo no povo: o segredo econômico da qualidade da populaçâo, Forense Universitária, Rio de Janeiro, Brazil.

Sen, Amartya (2001), Desigualdade reexaminada, Record, Rio de Janeiro, Brazil.

Sen, Amartya (1999), Desenvolvimento como Liberdade, Companhia das Letras, São Paulo, Brazil.

Train, Kenneth (2014), Métodos de elección discreta con simulación, Economía digital, Lima, Peru, < https://economiadigitals. blogspot.com.br/2017/05/metodos-de-eleccion-discreta-consimulacion-kenneth-train.html>, 19 June 2017.

Recibido: 20 de julio de 2016. Corregido: 27 de marzo de 2017. Aceptado: 13 de julio de 2017. 
Augusta Pelinski-Raiher. Doctor in economics from Federal University of Rio Grande do Sul. Researcher at the National Scientific and Technological Development Council (CNPq) and the Araucaria Foundation (PR). Researcher in the regional development area. Professor of the State University of Ponta Grossa (UEPG) in the Graduate Program in Social Sciences and professor in the economics department. The last publications: "Crescimento econômico, exportaçóes e tecnologia: o caso paranaense", Redes Revista do Desenvolvimento Regional, 21 (1), Santa Cruz do Sul, Brazil, pp. 84-102 (2016); "Uma análise multidimensional da pobreza nos municípios paranaenses em 2010", Revista de Estudos Sociais, 17 (34), Universidade Federal de Mato Grosso, Cuiabá, Brazil, pp. 228-248 (2015); "Crescimento econômico e sua convergência no estado do Paraná", Gestão \& Regionalidade, 31 (92), Universidade Municipal de São Caetano do Sul, Universidade Municipal de São Caetano do Sul, Brazil, pp. 136150 (2015).

Jandir Ferrera-de-Lima. Doctor in regional development from the Université du Québec à Chicoutimi (UQAC)/Canada. Researcher and scholar CNPq and Araucaria Foundation (PR). Researcher in the regional development area. Professor at the State University of Western Paraná (Unioeste) in the Graduate Program in Economics and Regional and Agribusiness Development. The last publications: "Indicadores de Base Econômica: uma aplicação para as Regiôes Brasileiras", Caderno de Geografia, 25 (43), Pontifícia Universidade Católica de Minas Gerais, Minas Gerais, pp. 206-220 (2015), "Desenvolvimento Economico Local em Assis Chateaubriand-PR", Desenvolvimento Regional em debate, 5 (1), Universidade do Contestado, Río Negrinho, Brazil, pp. 180-200 (2015), "O Perfil e o Crescimento Economico Agropecuario da Regiao Sul do Brasil entre 1996 e 2010”, Redes Revista do Desenvolvimento Regional, 20 (2), Santa Cruz do Sul, Brazil, pp. 69-84 (2015), "A indústria canavieira em Aldeias Altas e São Raimundo das Mangabeiras", Acta Tecnologica, 10, Instituto Federal de Educação, Ciência e Tecnologia do Maranhão, Campus Codó, Codó, Brazil, pp. 66-72 (2015). 